\title{
In vitro Evaluation of Trichoderma harzianum and Botanicals on the Radial Growth of Colletotrichum dematium Causing Anthracnose Disease of Groundnut (Arachis hypogaea L.)
}

\author{
Rupesh V. Patil*, Shashi Tiwari and Rohan D. Lokhande
}

Department of Plant Pathology, Naini Agricultural Institute, Sam Higginbottom University of Agriculture, Technology and Sciences, Allahabad 211007, U.P., India

*Corresponding author

\section{A B S T R A C T}

Keywords

Anthracnose, Colletotrichum dematium, Trichoderma harzianum and botanicals

Article Info

Accepted: 17 December 2018 Available Online: 10 January 2019
A study was conducted in vitro to control Colletotrichum dematium causing anthracnose disease of groundnut with Trichoderma harzianum and botanicals. Five botanicals viz., Datura leaf extract, Tulsi leaf extract, Garlic bulb extract, Neem oil and Eucalyptus oil at the rate of $5 \%$ were evaluated for their efficacy against the radial colony growth of $C$. dematium. The complete inhibition was obtained in Eucalyptus oil (100\%) followed by T. harzianum (71.01\%), datura leaf extract $(64.78 \%)$, tulsi leaf extract $(63.63 \%)$, neem oil $(49.14 \%)$ and garlic bulb extract $(43.35 \%)$. In the present study different culture media viz., malt extract agar, Czapek dox agar, corn meal agar, Martin's rose Bengal agar and oat meal agar were used for the study of different cultural characters of Colletotrichum dematium.

\section{Introduction}

The peanut, groundnut pea, or groundnut (Arachis hypogaea L.) is a native of South America but was early carried to the old world tropics by the Portuguese explorers. Groundnut is the one of the world's important oilseed crops. Groundnut is called as the 'King' of oilseeds. It is one of the most important food and cash crops in India. While being a valuable source of all the nutrients, it is a low-priced commodity. In groundnut several diseases like tikka, rust, peanut bud necrosis, collar rot, and anthracnose are constraints the yield and productivity. Anthracnose of groundnut caused by Colletotrichum dematium was first reported by Subrahmanyam et al., (2012). The term 'Anthracnose' literally means 'like coral' and first used by Fabre and Dunal to describe a disease of grapes in which blackening of tissues was characteristic feature black lesions, usually sunken caused by certain imperfect fungi that produce conidia in acervuli those 
are hyaline, one-celled, that is Colletotrichum (Jha et al., 2012). Colletotrichum dematium until recently was a relatively poorly known species in urgent need of epitypification. It was originally collected from a stem of Eryngium in France as well as solanaceous hosts and has been more recently recorded from numerous hosts such as a pathogen of chilli (Than et al., 2008). It has been also recorded as a pathogen of Polygonatum falcatum (Tomioka et al., 2008) and an endophyte of Pteromiscum sp. (Ren et al., 2008). Disease symptoms are reported to range from fruit rot to shoot, leaf, and flower blight, e.g., Sutton reported that in herb. It was represented that 216 collections from 37 countries on 118 different host genera.

Colletotrichum dematium is difficult to recognize based on morphological characteristics, mainly because different researchers have described conidia width differently. Colonies of putative $C$. dematium strains have been reported by Sutton (1992) to be very variable with white to pale mousegrey or grey-vinaceous patches with abundant setae and black, conical sclerotia. Conidia are formed in olive-grey to light vinaceoussalmon masses, and are 18-26 × 2-3 $\mu \mathrm{m}$, falcate, fusiform, and gradually tapered to each end (Sutton, 1992). Appressoria are medium brown, clavate, ovate to irregular, margin entire or slightly irregularly lobed (Sutton, 1992).

Keeping in view the economic importance of anthracnose disease, the present study has therefore been undertaken with the objective to isolate and identify the pathogen Colletotrichum dematium, to observe the effect of Trichoderma harzianum and certain botanicals on the radial growth of Colletotrichum dematium and to study the cultural characters of Colletotrichum dematium on different culture media.

\section{Materials and Methods}

An experiment was conducted to evaluate effect Trichoderma harzianum and botanicals on the radial growth of Colletotrichum dematium causing anthracnose of groundnut in vitro. The experiment was conducted in the Department of Plant Pathology, Sam Higginbottom University of Agriculture, Technology and Sciences, Allahabad (U.P.).

\section{Isolation and identification of pathogen}

Diseased leaves (anthracnose) of groundnut collected from research field of University were isolated by using standard procedure of Aneja (2004).

The pathogen was identified based on its cultural and morphological characters. Following single hyphal-tip technique, the fungus was transformed/subcultured aseptically onto the PDA slant in test tubes. Through frequent sub-culturing, the fungus was purified and pure culture was maintained on agar slants in test tubes stored in refrigerator for further studies.

\section{In vitro evaluation of biological agent}

Trichoderma harzianum was evaluated invitro on radial growth $C$. dematium applying Dual culture Technique (Dennis and Webster, 1971) and using Potato Dextrose Agar (PDA) as basal culture media.

\section{In vitro evaluation of botanicals}

A total of five botanicals viz. Datura leaf extract, Tulsi leaf extract, Garlic bulb extract, Neem oil and Eucalyptus oil at 5\% concentration were evaluated in vitro on radial growth of $C$. dematium applying Poison Food Technique (Nene and Thapliyal, 1993) and using Potato Dextrose Agar (PDA) as basal culture media. 


\section{Cultural characters of Colletotrichum dematium}

Different culture media viz., Malt extract agar, Czapek dox agar, Corn meal agar, Martin's rose Bengal agar and Oat meal agar were used for assessing the cultural characters such as colony diameter, growth rate and different phenotypic characters such as colony shape, colony margin, colony color and substrate color of Colletotrichum dematium.

Three replications were maintained for each media and were incubated at room temperature and observation recorded. The different colony characters were recorded in each medium by visual observation after 7 days of incubation.

Colony diameter of every culture was recorded daily for 7 days. Growth rate was calculated as the 7-day average of mean daily growth (mm per day).

\section{Collection and analysis of data}

After 7 days of incubation, radial growth (mm) of Colletotrichum dematium in petridishes was recorded. The radial growth (mm) of mycelium of each plate was measured by taking average of the two diameters taken right angles for each colony. Percentage inhibition of growth was calculated using the following formula:

Per cent growth inhibition $(\mathrm{I})=$

C - T $\times 100$

C

Where,

$\mathrm{C}=$ Growth of test fungus $(\mathrm{mm})$ in control plate

$\mathrm{T}=$ Growth of test fungus $(\mathrm{mm})$ in treatment plate

\section{Results and Discussion}

\section{Identification of Colletotrichum dematium}

Colony of putative $C$. dematium was very variable with white to pale mouse-grey or grey-vinaceous patches with abundant setae and black, conical sclerotia. The conidia are borne on conidiophores, each conidia was one celled hyaline, typically long, falcate, fusiform, and gradually tapered to each end the acervuli are main distinct features of this genus that are blackish to dark brown with pointed caps, the seta are hyaline and yellowish. The morphological observations of fungus were recorded by adapting slide culture technique. The fungus under study was identified as Colletotrichum dematium and its identification results were similar to the different fungal characters given by Sutton (1992) (Fig. 1).

\section{In vitro evaluation of bioagent and botanicals}

Different treatments tested in the present study gave appreciable inhibition in radial growth of C. Dematium as shown in the Table 1 . Minimum radial growth of $0.0 \mathrm{~mm}$ was observed in $\mathrm{T}_{6}$ (Eucalyptus oil @ 5\%) which is statistically significant followed by $\mathrm{T}_{1}$ (Trichoderma harzianum) $17 \mathrm{~mm}, \mathrm{~T}_{2}$ (Datura leaf extract@ $@ 5 \%$ ) 20.66 mm, $\mathrm{T}_{3}$ (Tulsi leaf extract @ 5\%) $21.33 \mathrm{~mm}, \mathrm{~T}_{5}$ (Neem oil @ 5\%) $29.83 \mathrm{~mm}$ and $\mathrm{T}_{4}$ (Garlic bulb extract @ 5\%) $33.13 \mathrm{~mm}$ as compared to control (58.66 $\mathrm{mm})$.Maximum per cent growth inhibition of Colletotrichum dematium $100 \%$ was obtained by $\mathrm{T}_{6}$ (Eucalyptus oil @ 5\%) followed by $\mathrm{T}_{1}$ (Trichoderma harzianum) $71.01 \%, \mathrm{~T}_{2}$ (Datura leaf extract@ @ 5\%) 64.78\%, $\mathrm{T}_{3}$ (Tulsi leaf extract @ 5\%) 63.63\%, $\mathrm{T}_{5}$ (Neem oil @ 5\%) 49.14\% and $\mathrm{T}_{4}$ (Garlic bulb extract @ 5\%) $43.35 \%$ as compared to control (Table 1; Fig. 2 and 3$)$. 
Table.1 Effect of bioagent and botanicals on the radial growth and per cent growth inhibition of Colletotrichum dematium

\begin{tabular}{|c|l|c|c|}
\hline \multicolumn{2}{|c|}{ Treatments } & Radial growth $\mathbf{( m m )}$ & Growth inhibition $(\boldsymbol{\%})$ \\
\hline $\mathbf{T}_{\mathbf{0}}$ & Control & 58.66 & 0.0 \\
\hline $\mathbf{T}_{\mathbf{1}}$ & $\begin{array}{l}\text { Trichoderma } \\
\text { harzianum }\end{array}$ & 17 & 71.01 \\
\hline $\mathbf{T}_{\mathbf{2}}$ & Datura leaf extract & 20.66 & 64.78 \\
\hline $\mathbf{T}_{\mathbf{3}}$ & Tulsi leaf extract & 21.33 & 63.63 \\
\hline $\mathbf{T}_{\mathbf{4}}$ & Garlic bulb extract & 33.13 & 43.35 \\
\hline $\mathbf{T}_{\mathbf{5}}$ & Neem oil & 29.83 & 49.14 \\
\hline $\mathbf{T}_{\mathbf{6}}$ & Eucalyptus oil & $\mathbf{0}$ & $\mathbf{1 0 0}$ \\
\hline & $\quad$ C. $\mathbf{D}$. $\mathbf{P}=\mathbf{0 . 0 5})$ & $\mathbf{6 . 8 9 7}$ & - \\
\hline & S.Ed. $\mathbf{( + )}$ & $\mathbf{3 . 2 1 3}$ & - \\
\hline
\end{tabular}

Table.2 Mean colony diameter and growth rate of Colletotrichum dematium on different culture media

\begin{tabular}{|c|c|c|c|}
\hline Sr.No. & Media & $\begin{array}{c}\text { Mean colony } \\
\text { diameter }(\mathbf{m m})\end{array}$ & $\begin{array}{c}\text { Growth rate } \\
(\mathbf{m m} / \mathbf{d a y})\end{array}$ \\
\hline $\mathbf{1}$ & Malt extract agar & 68.33 & 9.76 \\
\hline $\mathbf{2}$ & Czapek dox agar & $\mathbf{8 9}$ & $\mathbf{1 2 . 7 1}$ \\
\hline $\mathbf{3}$ & Corn meal agar & 63.50 & 9.07 \\
\hline $\mathbf{4}$ & Martin’s rose Bengal agar & 48.00 & 6.85 \\
\hline $\mathbf{5}$ & Oat meal agar & 73.16 & 10.45 \\
\hline & C. D. $(\mathbf{P}=\mathbf{0 . 0 5})$ & $\mathbf{6 . 0 6 8}$ & - \\
\hline & S.Ed. $(\underline{+})$ & $\mathbf{2 . 7 2 0}$ & - \\
\hline
\end{tabular}

Fig.1 Effect of bioagent (Trichoderma harzianum) on radial growth of Colletotrichum dematium

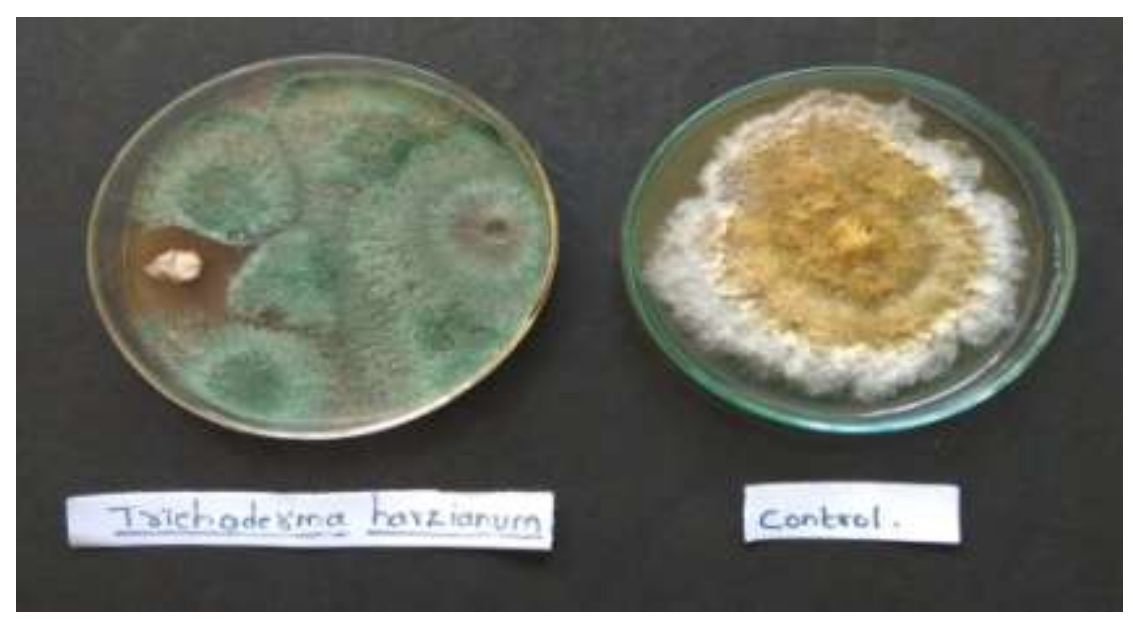


Fig.2 Effect of botanicals on radial growth of Colletotrichum dematium. Where, A- Control, BDatura leaf extract (5\%), C- Tulsi leaf extract (5\%), D- Garlic bulb extract (5\%), E- Neem oil $(5 \%)$, F- Eucalyptus oil (5\%)

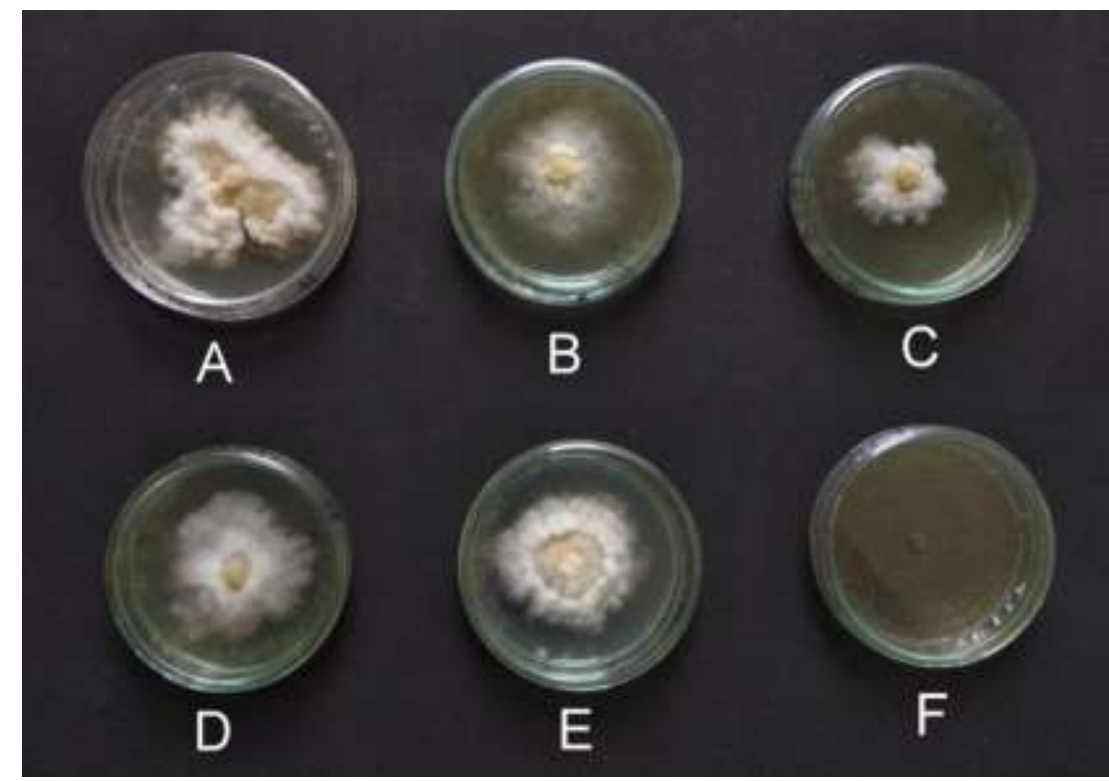

Fig.3 Growth of Colletotrichum dematium on different culture media

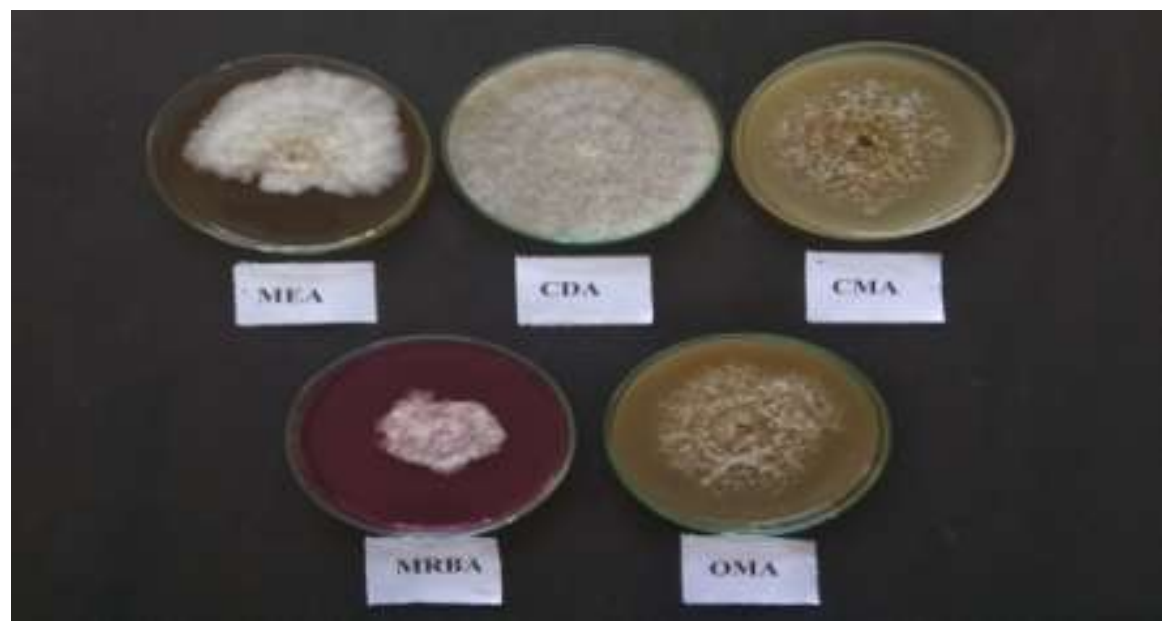

The minimum radial growth was observed in $\mathrm{T}_{6}$ (Eucalyptus oil @ 5\%) whereas the maximum radial growth was observed in $\mathrm{T}_{0}$ (Control). The probable reason for such findings may be that the mycelial growth of the test pathogen (Colletotrichum dematium) was checked due to the fungicidal properties of essential oil used during the experiment. Similar findings have been reported by Ramezani et al., (2002).
Cultural characters of Colletotrichum dematium on different culture media

There was significant difference among different culture media with respect to colony diameter which ranged from 48 to $89 \mathrm{~mm}$. The maximum mean colony diameter as observed in Czapek dox agar $(89 \mathrm{~mm})$ followed by Oat meal agar $(73.16 \mathrm{~mm})$, Malt extract agar $(68.33 \mathrm{~mm})$, Corn meal agar 
(63.50 mm) and Martin's rose Bengal agar $(48 \mathrm{~mm})$. Colletotrichum dematium growth rate ranges from 6.85 to $12.71 \mathrm{~mm} /$ day. The fastest growth was recorded $12.71 \mathrm{~mm} /$ day on Czapek dox agar followed by Oat meal agar (10.45 mm/day), Malt extract agar (9.76 $\mathrm{mm} /$ day), Corn meal agar (9.07 mm/day) and Martin's rose Bengal agar $(6.85 \mathrm{~mm} /$ day $)$ (Table 2). The cultural characters and growth of Colletotrichum dematium varied on different media. This might be due to the variation in the nutritional requirement of the fungus. There was a wide variation in the colony shape, margin and colour of Colletotrichum dematium on different culture media. Similar observations were made by Denobys and Baudry (1995), Kuramae et al., (1997) and Manjunath (2009).

\section{References}

Aneja, K.R. (2004). Experiment in Microbiology, Plant pathology and Biotechnology, 4th Edition. New Age International (P) Ltd. Publisher, New Delhi. Pp.437-450.

Dennis, C. and Webster, J. (1971). Antagonistic properties of speciesgroup of Trichoderma and hyphal interactions. Transactions of the British Mycological Society, 57: 363-369.

Denobys, B. and Baudry, A. (1995). Species identification and pathogenicity strictly of France Colletotrichum strains isolated from strawberry using morphological and cultural characteristics. Phytopathology, 85: 5357.

Jha, A., Tiwari, S., Zacharia, S. and Simon, S. (2012). First report of anthracnose disease on groundnut caused by Colletotrichum dematium from Allahabad (Uttar Pradesh) in India. International Journal of Agricultural Sciences, 8(2): 465-467.

Kuramae, E.E., Lopes, C.R., Souza, N.L. and
Machado, (1997). Morphological and molecular characterization of Colletotrichum spp. from citrus orchads affected by post bloom fruit drop in Brazil. European Journal of Plant Pathology, 103: 323-329.

Manjunath, (2009). Morphological and Molecular characterization of Alternaria alternata and Colletotrichum gloeosporioides incitants of leaf blight and anthracnose disease as of Noni and their Management, M.Sc.(Ag) Thesis, Tamil Nadu Agricultural University, Coimbatore, India, Pp: 222.

Nene, Y.L., Thapliyal, P.N., Srivastava, S.S.L, Sarbhoy, A.K. and Khare, M.N. (1972). Seed and seedling rots of soybean. Fungi and Nematode, 28: 266.

Ramezani, H., Singh, H.P., Batish, D.R., Kohli, R.K. and Dargan, J.S. (2002). Fungicidal effect of volatile oils from Eucalyptus citriodora and its major constituent citronellal. New Zealand Plant Protection, 55: 327-330.

Ren, Y.H., Strobel, G.A., Graff, J.C., Jutila, M., Park, S.G., Gosh, S., Teplow, D., Condron, M., Pang, E., Hess, W.M. and Moore, E. (2008). Colutellin A, an immunosuppressive peptide from Colletotrichum dematium. Microbiology, 154: 1973-1979

Subrahmanyam, P., Wongkaew, S., Reddy, D.V. R., Demski, J.W., McDonald, D., Sharma, S.B. and Smith, D.H. (2012). Field diagnosis of groundnut diseases. Information Bulletin No. 36. International Crops Research Institute for the Semi-Arid Tropics. Patancheru, (A.P.) India. Pp. 24-25.

Sutton, B.C. (1992). The genus Glomerella and its anamorph Colletotrichum. In: Colletotrichum: biology, pathology and control (eds. J.A. Bailey and M.J. Jeger). CAB International, Wallingford: 1-26.

Than, P.P., Jeewon, R., Hyde, K.D., 
Pongsupasamit, S., Mongkolporn, O., Taylor, P.W.J. (2008). Characterization and pathogenecity of Colletotrichum species associated with anthracnose disease of chilli (Capsicum spp.) in Thailand. Plant Pathology, 57(53): 562-
572.

Tomioka, K., Moriwaki, J. and Sato, T. (2008). Anthracnose of Polygonatum falcatum caused by Colletotrichum dematium. Journal of General Plant Pathology, 74: 402-404.

\section{How to cite this article:}

Rupesh V. Patil, Shashi Tiwari and Rohan D. Lokhande. 2019. In vitro Evaluation of Trichoderma harzianum and Botanicals on the Radial Growth of Colletotrichum dematium Causing Anthracnose Disease of Groundnut (Arachis hypogaea L.). Int.J.Curr.Microbiol.App.Sci. 8(01): 2657-2663. doi: https://doi.org/10.20546/ijcmas.2019.801.279 